\title{
Proteomic Analysis of Glomerular Proteins in Primary and Bucillamine-induced Membranous Nephropathy
}

\author{
Hajime Kaga \\ Akita University Graduate School of Medicine \\ Hirotoshi Matsumura ( $\sim$ matsumuh@gipc.akita-u.ac.jp ) \\ Akita University \\ Takehiro Suzuki \\ RIKEN Center for Sustainable Research Science \\ Naoshi Dohmae \\ RIKEN Center for Sustainable Research Science \\ Masafumi Odaka \\ Akita University \\ Atsushi Komatsuda \\ Ogachi Central Hospital \\ Naoto Takahashi \\ Akita University Graduate School of Medicine \\ Hideki Wakui \\ Akita University
}

\section{Research Article}

Keywords: Glomerular Proteins, Membranous Nephropathy, potential disease

Posted Date: November 12th, 2021

DOI: https://doi.org/10.21203/rs.3.rs-988234/v1

License: (우 This work is licensed under a Creative Commons Attribution 4.0 International License. Read Full License 


\section{Abstract}

The aim of this study was to characterize glomerular proteins in primary membranous nephropathy (pMN) and drug-induced secondary MN (sMN) by laser microdissection and comparative proteomic analysis. We used renal biopsy specimens from 6 patients with anti-phospholipase A2 receptor autoantibody (PLA2R Ab) (+) pMN, 6 patients with PLA2R Ab (-) pMN, 6 patients with bucillamine (BCL)-induced SMN, and 5 control cases (time 0 transplant biopsies). Proteins were extracted from laser-microdissected glomeruli and analyzed using mass spectrometry. The quantification values of protein abundance in each MN group were compared with those in the control group. More than 800 proteins with high confidence were identified. Principal component analysis revealed a different distribution between the pMN and sMN groups. For further analysis, 441 proteins matched with $\geq 3$ peptides were selected. Among the pMN and SMN groups, we compared the profiles of several protein groups based on the structural and functional characteristics, such as immunoglobulins, complements, complement-regulating proteins, podocyteassociated proteins, glomerular basement membrane proteins, and several proteins that are known to be associated with kidney diseases, including MN. Between the pMN and BCL-induced SMN groups, we observed common and different alterations in protein levels such as known disease-associated proteins and potential disease marker proteins.

\section{Introduction}

Membranous nephropathy (MN) is a common cause of nephrotic syndrome (NS) in adults. Histopathological features in MN are subepithelial immune deposits and associated alterations in the glomerular basement membranes (GBM) ${ }^{1,2}$. After the discovery of circulating antibodies specific for native podocyte antigens, a serology-based diagnostic approach was proposed ${ }^{1,2}$.

Primary MN (pMN), responsible for approximately $70 \%$ to $80 \%$ of cases, is an autoimmune disease mainly caused by circulating anti-phospholipase A2 receptor antibodies (PLA2R Abs) ${ }^{1,2}$. A predominance of the immunoglobulin (Ig) G4 subclass is characteristic of $\mathrm{pMN}^{1,2}$. Secondary $\mathrm{MN}(\mathrm{sMN})$ in the remaining $\mathrm{MN}$ cases is caused by infections, drugs, malignancies, or systemic autoimmune diseases ${ }^{3}$. Bucillamine (BCL), a disease-modifying antirheumatic drug developed in 1987 in Japan ${ }^{4,5}$, is widely used for the treatment of rheumatoid arthritis in Japan. This agent has a chemical structure similar to penicillamine and causes $\mathrm{sMN}^{4,5}$. A predominance of the lgG4 subclass was not observed in a case-series study from a Japanese institute ${ }^{4}$. This suggests different immunological mechanisms between $\mathrm{pMN}$ and BCL-induced sMN.

Renal biopsy is a traditional approach for the definite diagnosis of $\mathrm{MN}$, but it may not be sufficient to establish the true nature of $\mathrm{MN}^{1}$. Recent progress in proteomic analysis has furthered our understanding of renal physiological processes ${ }^{6}$. However, in most proteomic approaches to chronic kidney diseases including MN, urine and/or serum samples are analyzed ${ }^{7}$. Recently, Kawata et al. ${ }^{8}$ and Ravindran et al. ${ }^{9}$ reported the profiles of protein groups, such as Igs, complements, and complement-regulating proteins, in pMN and exostosins-associated SMN using laser-microdissected glomeruli from formalin-fixed paraffin-embedded tissue sections.

In the present study, we performed laser-microdissection and comparative proteomic analysis of glomerular proteins in PLA2R Abpositive (PLA2R (+)) pMN, PLA2R Ab-negative (PLA2R (-)) pMN, BCL-induced sMN, and control cases (time 0 transplant biopsies). We then characterized the profiles of several protein groups based on the structural and functional characteristics, such as Igs, complements, complement-regulating proteins, podocyte-associated proteins, GBM proteins, and known kidney disease-related proteins, and found different protein profiles between PMN and BCL-induced SMN.

\section{Results}

Clinicopathological characteristics of MN patients and transplantation donors. The clinicopathological features of our MN patients and transplantation donors are shown in Tables 1 and 2 . The median ages of patients with PLA2R (+) pMN, PLA2R (-) PMN, or BCL-induced SMN, and healthy transplantation donors were $63,78,45$, and 53 years, respectively. There was a female predominance among patients with BCL-induced SMN. In the pMN groups, 10 of the 12 patients developed NS. In the BCL-induced sMN group, 2 of the 6 patients developed NS during BCL therapy and proteinuria improved after BCL discontinuation. Renal function was preserved in all groups. Glomerular IgG deposition was observed in all MN patients. IgG4 predominance was observed in the pMN groups, whereas IgG1 deposition was characteristic, in addition to IgG4 deposition, in the BCL-induced sMN group. Co- 
deposition of $\operatorname{Ig} \mathrm{A}$, IgM, and $\mathrm{C} 1 \mathrm{q}$ was more frequent in the $\mathrm{BCL}$-induced $\mathrm{SMN}$ group than in the $\mathrm{pMN}$ groups, whereas C3 deposition was noted in most MN patients. MN stages were variable among patients in all groups.

Comparative proteomic analysis. In our proteomic analysis of glomerular proteins extracted from laser-microdissected glomeruli of the enrolled subjects, principal component analysis revealed a different distribution pattern between the pMN and sMN groups (Figure 1). We were able to identify 846 proteins with high confidence (experimental $Q<0.01$ ), and further selected 441 proteins that were matched with $\geq 3$ peptides. Proteins with increased levels in the MN groups (PLA2R (+)/control, PLAR (-)/control, and $\mathrm{BCL} /$ control ratios of $>2.5$ ) and proteins with decreased levels in the MN groups (PLA2R (+)/control, PLAR (-)/control, and $\mathrm{BCL} /$ control ratios of $<0.4$ ) are shown in Tables 3-7. Proteins that increased or decreased with medium or high confidence (adjusted $P<0.05$ or $<0.01)$ are indicated in these tables.

Igs are summarized in Table $3 . \lg \gamma 1, \lg \gamma_{2}, \lg \gamma_{4}, \lg a$, and $\lg \mu$ heavy chains, and $\lg K$ and $\lg \lambda$ light chains were detected. Increased levels of $\lg \gamma_{4}, \lg \alpha$, and $\lg \mu$ heavy chains, and $\lg \mathrm{k}$ light chain were found in all MN groups. Levels of $\lg \gamma_{1} 1$ and $\lg \gamma_{2}$ heavy chains, and $\lg \lambda$ light chain also increased (>1.8) in all MN groups.

Complements and complement-regulating proteins are summarized in Table 4. Complement C3, C4A, C4A3, and C9 were detected. These complement proteins increased in all MN groups. Complement factor H-related proteins (CFHR1 and CFHR5), clusterin, complement receptor 1, C4b-binding protein a chain, and vitronectin were also detected. Among them, CFHR5 was abundant in all MN groups, whereas CFHR1 was abundant in the BCL-induced SMN group.

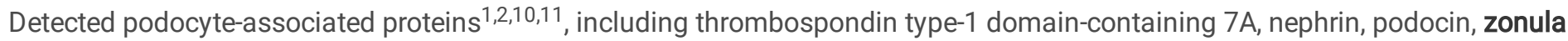
occludens-1, F-actin capping protein a2 (CapZ) ${ }^{12}$, synaptopodin, a-actinin-4, myosin-9, podocalyxin ${ }^{13}$, integrin a3, nestin ${ }^{14,15}$, and vimentin ${ }^{14}$, are summarized in Table 5. In the PLA2R Ab (+) pMN group, CapZ, nestin, and vimentin were abundant. Lower levels of nestin were observed in the BCL-induced SMN group.

Detected GBM proteins ${ }^{16}$, including type IV collagen a chains, laminin chains, nidogen-1, agrin, and heparan sulfate proteoglycan (HSPG) perlecan, are summarized in Table 6. Lower levels of type IV collagen a1 chain were observed in all MN groups. The levels of the other proteins were almost unchanged.

Other glomerular proteins, including type VII collagen a 1 chain ${ }^{17}$, type XVIII collagen a 1 chain ${ }^{18}$, calmodulin ${ }^{19}$, polyubiquitin ${ }^{20}$, and F-box only protein 50 (previously known as non-specific cytotoxic cell receptor protein 1, now known as FBX050 ubiquitin ligase) ${ }^{21}$, are summarized in Table 7. Among them, the levels of type XVIII collagen a1 chain, calmodulin, polyubiquitin, and FBXO50 ubiquitin ligase increased in all MN groups. The levels of type VII collagen a1 chain increased in the BCL-induced SMN group.

\section{Discussion}

Kawata et al. ${ }^{8}$ and Ravindran et al. ${ }^{9}$ recently reported the proteomic profiles of Igs, complement proteins, and complementregulating proteins in pMN and exostosins-associated sMN using laser-microdissected glomeruli and mass spectrometry. In the present study, we performed comparative proteomic analysis of glomerular proteins extracted from laser-microdissected glomeruli of PLA2R (+) pMN, PLA2R (-) pMN, and BCL-induced sMN patients and transplantation donors.

In a study by Kawata et al. ${ }^{8}$, post-transplant kidneys (at the 1-hour biopsy samples after reperfusion of the blood) were used as the controls. They also reported that glomerular structural proteins and podocyte-related proteins were detected as the major proteins in pre-transplant kidneys (at the 0-hour biopsy samples after perfusion with preservation solution) ${ }^{8}$. In a study by Ravindran et al. ${ }^{9}$ and in the present study, time 0 biopsies were used as the controls. As discussed below, similar results regarding Igs, complement proteins, and complement-regulating proteins, were obtained in these studies.

In studies by Kawata et al. ${ }^{8}$ and Ravindran et al. ${ }^{9}$, peptide identifications were accepted at greater than $95 \%$ probability, and the proteins identified had at least 2 matching peptides. In our proteomic analysis, principal component analysis demonstrated a different distribution between the pMN and sMN groups (Figure 1). More than 800 proteins with high confidence (experimental $Q$ $<0.01$ ) were identified, and 441 proteins matched with $\geq 3$ peptides were further selected for more precise analysis. In addition to Igs, complement proteins, and complement-regulating proteins, we listed podocyte-associated proteins, GBM proteins, and other 
glomerular proteins that are known to be associated with kidney diseases including MN. After analyzing the abundance of these proteins, proteins in each $\mathrm{MN}$ group were compared with those in the control group.

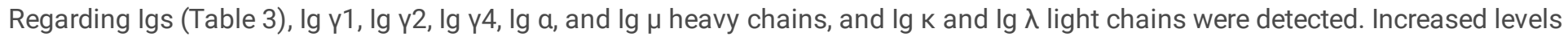
of these Ig heavy and light chains were found in all MN groups. This suggests that polyclonal co-deposits of $\lg G \lg A$, and $\lg M$ are detected by nLC-MC/MS in all MN groups. In a study by Ravindran et al. ${ }^{9}$, increased levels of $\lg \mathrm{Y}^{1}, \lg \mathrm{Y} 2$, and $\lg \mathrm{Y}^{4}$ heavy chains were also observed in their patients with PLA2R (+) pMN and exostosins-associated sMN. Although pMN is considered an IgG4dominant disease, PLA2R Abs of other IgG subclasses are present in the majority of patients with PLA2R-associated $\mathrm{MN}^{22}$.

Regarding complement proteins and complement-regulating proteins (Table 4), the observed levels were largely consistent with those in pMN reported by Kawata et al. ${ }^{8}$ and in PLA2R-associated pMN and exostosins-associated sMN reported by Ravindran et al. ${ }^{9}$ except for CFHR1. Increased levels of C3, C4A, C9, and CFHR5 were also observed in all MN groups. This suggests common activation mechanisms in the complement cascade and regulatory pathways between pMN and BCL-induced sMN.

In our proteomic analysis, main podocyte-associated proteins were detected (Table 5). Among them, increased levels of the actin capping protein CapZ ${ }^{12}$ were observed in the $\mathrm{pMN}$ groups. As CapZ contributes to the formation and maintenance of a specialized cell-cell contacts between podocyte foot processes and barrier function ${ }^{12}$, increased CapZ may have a protective role in injured podocytes. Regarding podocyte nestin expression, there were controversial findings in the puromycin aminonucleoside-induced rat nephrosis model and diseased human kidneys ${ }^{14,15}$. Upregulation of podocyte nestin was observed in the rat model ${ }^{14}$, whereas podocyte nestin expression was reduced in patients with proteinuria ${ }^{15}$. In our study, the level of nestin increased in PLA2R (+) pMN, whereas it decreased in BCL-induced SMN. The reason for this difference is not clear at present.

Main GBM proteins ${ }^{16}$ were also detected in our proteomic analysis (Table 6). In all MN groups, the levels of type IV collagen, laminins, nidogens-1, agrin, HSPG perlecan were unaltered, except for type IV collagen a1 chain. As mature GBM are composed of type IV collagen a3a4a5 chains $^{16}$, decreased type IV collagen a 1 chain may have a minor role in GBM assembly in MN. Glomerular abnormalities can be classified into 4 stages in $\mathrm{MN}^{2}$. As the $\mathrm{MN}$ stages in our patients were variable in all $\mathrm{MN}$ groups, GBM protein components may be preserved even at advanced stages.

We further listed possible disease-associated proteins in MN (Table 7). Among them, an increased level of type VII collagen was found in BCL-induced SMN. Increased expression of type VII collagen was also observed in several glomerular diseases in the previous study ${ }^{17}$. On the other hand, increased levels of type XVIII collagen a1 chain were found in all MN groups. In the previous study of mice lacking type XVIII collagen a1 chain, podocyte foot process effacement was observed ${ }^{18}$. Up-regulation of this type of collagen chain in MN may play a role in structural maintenance in injured podocytes. Regarding signaling proteins, increased levels of calmodulin were observed in all MN groups. This may be associated with the direct effects of $\mathrm{Ca}^{2+} / \mathrm{calmodulin}$ on actin filament formation ${ }^{19}$ in injured podocytes. Regarding the ubiquitin-proteasome system ${ }^{23}$, increased levels of polyubiquitin ${ }^{20}$ and $\mathrm{FBXO50}$ ubiquitin ligase ${ }^{21}$ were noted in all $\mathrm{MN}$ groups, suggesting upregulation of the ubiquitin-proteasome system in podocytes in response to injury in $\mathrm{MN}$.

In conclusion, this is the first report of comparative proteomic analysis of glomerular proteins extracted from laser-microdissected glomeruli in pMN and BCL-induced SMN. Between these MN groups, we observed common and different alterations in protein levels such as known disease-associated proteins and potential disease marker proteins. Proteomic analysis of glomerular proteins is a useful approach to improve our understanding of the pathogenesis of glomerular diseases, including MN.

\section{Methods}

Patients. We enrolled 6 patients with PLA2R (+) pMN, 6 patients with PLA2R (-) pMN, 6 patients with BCL-induced sMN, and 5 healthy transplantation donors (time 0 transplant biopsies) as controls in this study. All patients and healthy donors were Japanese. pMN was diagnosed based on renal biopsy findings and screening for causes of sMN. All patients in the pMN groups did not present with any clinical findings suggesting the causes of $\mathrm{sMN}^{3}$. BCL-induced $\mathrm{sMN}$ was diagnosed based on renal biopsy findings and clinical course (development of proteinuria after BCL therapy and improvement of proteinuria after discontinuing 
$B C L)^{4,5}$. All patients in the BCL-induced SMN group did not present with any clinical findings suggesting the causes of sMN other than BCL exposure ${ }^{3}$.

Clinicopathological analysis. Clinical data of patients and transplantation donors were collected from medical records for age, sex, urinary protein, serum albumin, and creatinine $(\mathrm{Cr})$ at the time of renal biopsy. For patients with $\mathrm{BCL}$-induced sMN, urinary protein levels during $B C L$ therapy and after discontinuing $B C L$ were also collected. NS was defined as urinary protein $\geq 3.5 \mathrm{~g} / \mathrm{day}$ or $\mathrm{g} / \mathrm{gCr}$ and hypoalbuminemia (serum albumin $\leq 3.0 \mathrm{~g} / \mathrm{dL}$ ). The estimated glomerular filtration rate was calculated using the formula for Japanese patients ${ }^{24}$. Circulating PLA2R Abs were measured in $\mathrm{PMN}$ patients using enzyme-linked immunosorbent assay (ELISA), in-house ELISA, and a standardized commercial ELISA (Euroimmun, Lübeck, Germany), as described previously ${ }^{25}$.

Renal biopsy specimens were processed using standard techniques for light, immunofluorescence, and electron microscopy. Formalin-fixed, paraffin-embedded sections were stained with hematoxylin and eosin, periodic acid-Schiff, Masson trichrome, and periodic acid-methenamine silver. Cryostat sections for immunofluorescence microscopy were stained with fluorescein isothiocyanate-conjugated rabbit polyclonal antibodies against human $\lg G$, $\lg A, \lg \mathrm{M}, \mathrm{k}, \lambda, \mathrm{C} 3$, and C1q (DakoCytomation, Glostrup, Denmark). Further studies to determine IgG subclasses were performed as described previously ${ }^{26}$.

Laser microdissection and proteomic analysis. For each case, 8- $\mu \mathrm{m}$-thick formalin-fixed paraffin-embedded renal biopsy sections were mounted on PEM-Membrane slides (MicroDissect GmbH, Herborn, Germany). Using a Leica LMD7000 laser microdissection system (Leica Microsystems, Tokyo, Japan), the glomeruli were microdissected to reach approximately 1,000,000-4,000,000 $\mu \mathrm{M}^{2}$ per case. The dissected glomeruli were treated with approximately 100-200 $\mu \mathrm{L}$ of TE Buffer (Promega Corporation, Madison, WI, USA) containing $0.002 \%$ hexadecyldimethyl(3-sulfopropyl) ammonium hydroxide inner salt (Tokyo Medical Industry, Tokyo, Japan) in $0.5-\mathrm{mL}$ microcentrifuge tubes. Glomerular proteins were extracted in the microcentrifuge tubes by sonication.

Nano-liquid chromatography-tandem mass spectrometry (nLC-MS/MS) was performed as described previously ${ }^{27}$. In brief, extracted glomerular proteins were digested with trypsin. Tryptic digests $(0.01 \mu \mathrm{g})$ were separated on an Easy-nLC 1200 (Thermo Fisher Scientific, Walthman, MA, USA) using a C18 analytical column (NTCC-360/75-3-155, Nikkyo Technos, Tokyo, Japan). The separated peptides were then analyzed on a Q-Exactive HF-X mass spectrometer (Thermo Fisher Scientific) coupled with an Easy-nLC 1200 (Thermo Fisher Scientific).

Data analysis. Data analysis was performed as described previously ${ }^{27}$. In brief, the data obtained in the nLC-MS/MS experiments were analyzed using Proteome Discover 2.4 (Thermo Fisher Scientific) and Mascot Server 2.7 (Matrix Science; http://www.matrixscience.com/server.html). The National Center for Biotechnology Information non-redundant database is a predefined database for protein identification. The reproducibility of the data for the samples from each group was confirmed through principal component analysis ${ }^{28}$. The fold-change values obtained during the relative quantification of protein abundance were compared between each MN group and the control group (expressed as PLA2R (+)/control, PLA2R (-)/control, and $\mathrm{BCL} /$ control ratios). If the denominator of a fraction was zero or almost zero, the relative protein abundance ratio was defined as 100. If the numerator of a fraction was zero or almost zero, the relative protein abundance ratio was defined as 0.01 .

Medical ethics. The study was approved by the Ethics Committees of Akita University Hospital (approval number: 1830) and RIKEN Center (approval number: Wako3 2019-17). All procedures performed in studies involving human participants were in accordance with the ethical standards and with the 1964 Helsinki declaration and its later amendments or comparable ethical standards. Informed consent was obtained from all individual participants included in the study.

\section{Declarations}

\section{Acknowledgements}

The authors thank all the doctors at our affiliated hospitals for the referral of the patients. This study was supported in part by the Japanese Society for the Promotion of Science Grant-in-Aid for Scientific Research Grant 19K08694 (to A.K.), and private donations from Dr. Ken Satoh, Satoh Naika Clinic, Sakata, Japan, and Dr. Masaru Togashi, Akita Renal, Collagen and Rheumatic Disease Clinic, Akita, Japan. 
H.K. performed the histological study of renal biopsies. T.S. and N.D. performed proteomic analysis. H.M., M.O., A.K., N.T., and H.W. carried out the design and drafted the manuscript. All authors gave their approval of the manuscript to be published.

\section{Competing interests}

N.T. has received grants and personal fees from Novartis Pharmaceuticals, grants and personal fees from Pfizer, grants and personal fees from Otsuka Pharmaceutical, grants from Kyowa Kirin, grants from Astellas Pharma, grants from Asahi Kasei Pharma, grants from Ono Pharmaceutical, and grants from Mochida Pharmaceuticals, outside of the submitted work. The remaining authors declare that they have no competing interests.

\section{References}

1. De Vriese, A. S., Glassock, R. J., Nath, K. A., Sethi, S. \& Fervenza, F. C. A proposal for a serology-based approach to membranous nephropathy. J. Am. Soc. Nephrol. 28, 421-430 (2017).

2. Pozdzik, A. et al. Membranous nephropathy and anti-podocytes antibodies: implications for the diagnostic workup and disease management. Biomed. Res. Int. 2018, 6281054 (2018).

3. Moroni, G. \& Ponticelli, C. Secondary membranous nephropathy. a narrative review. Front. Med. (Lausanne). 7, 611317 (2020).

4. Nagahama, K. et al. Bucillamine induces membranous glomerulonephritis. Am. J. Kidney Dis. 39, 706-712 (2002).

5. Hoshino, J. et al. Outcome and treatment of bucillamine-induced nephropathy. Nephron Clin. Pract. 104, c15-c19 (2006).

6. Rinschen, M. M., Limbutara, K., Knepper, M. A., Payne, D. M. \& Pisitkun, T. From molecules to mechanisms: functional proteomics and its application to renal tubule physiology. Physiol. Rev. 98, 2571-2606 (2018).

7. Taherkhani, A., Farrokhi Yekta, R., Mohseni, M., Saidijam, M. \& Arefı Oskouie, A. Chronic kidney disease: a review of proteomic and metabolomic approaches to membranous glomerulonephritis, focal segmental glomerulosclerosis, and IgA nephropathy biomarkers. Proteome Sci. 17, 7 (2019).

8. Kawata, N. et al. Proteomics of human glomerulonephritis by laser microdissection and liquid chromatography-tandem mass spectrometry. Nephrology (Carlton). 25, 351-359 (2020).

9. Ravindran, A. et al. Proteomic analysis of complement proteins in membranous nephropathy. Kidney Int. Rep. 5, 618-626 (2020).

10. Kopp, J. B. et al. Podocytopathies. Nat. Rev. Dis. Primers. 6, 68 (2020).

11. Blaine, J. \& Dylewski, J. Regulation of the actin cytoskeleton in podocytes. Cells. 9, 1700 (2020).

12. van Duijn, T. J., Anthony, E. C., Hensbergen, P. J., Deelder, A. M. \& Hordijk, P. L. Rac1 recruits the adapter protein CMS/CD2AP to cell-cell contacts. J. Biol. Chem. 285, 20137-20146 (2010).

13. Zhang, W., Ren, Y. \& Li, J. Application of miR-193a/WT1/PODXL axis to estimate risk and prognosis of idiopathic membranous nephropathy. Ren. Fail. 41, 704-717 (2019).

14. Zou, J. et al. Upregulation of nestin, vimentin, and desmin in rat podocytes in response to injury. Virchows Arch. 448, 485-492 (2006).

15. Su, W. et al. Expression of nestin in the podocytes of normal and diseased human kidneys. Am. J. Physiol. Regul. Integr. Comp. Physiol. 292, R1761-R1767 (2007).

16. Naylor, R. W., Morais, M. R. P. T. \& Lennon, R. Complexities of the glomerular basement membrane. Nat. Rev. Nephrol. 17, 112127 (2021). 
17. Onetti Muda, A., Ruzzi, L., Bernardini, S., Teti, A. \& Faraggiana, T. Collagen VIl expression in glomerular sclerosis. J. Pathol. 195, 383-390 (2001).

18. Kinnunen, A. I. et al. Lack of collagen XVIII long isoforms affects kidney podocytes, whereas the short form is needed in the proximal tubular basement membrane. J. Biol. Chem. 286, 7755-7764 (2011).

19. Izadi, M., Hou, W., Qualmann, B. \& Kessels, M. M. Direct effects of $\mathrm{Ca}^{2+} /$ calmodulin on actin filament formation. Biochem. Biophys. Res. Commun. 506, 355-360 (2018).

20. Meyer-Schwesinger, C. et al. Ubiquitin C-terminal hydrolase-L1 activity induces polyubiquitin accumulation in podocytes and increases proteinuria in rat membranous nephropathy. Am. J. Physiol. 178, 2044-2057 (2011).

21. Kallio, H. et al. Characterization of non-specific cytotoxic cell receptor protein 1: a new member of the lectin-type subfamily of Fbox proteins. PLoS One. 6, e27152 (2011).

22. van de Logt, A. E., Fresquet, M., Wetzels, J. F. \& Brenchley, P. The anti-PLA2R antibody in membranous nephropathy: what we know and what remains a decade after its discovery. Kidney Int. 96, 1292-1302 (2019).

23. Meyer-Schwesinger, C. The ubiquitin-proteasome system in kidney physiology and disease. Nat. Rev. Nephrol. 15, 393-411 (2019).

24. Matsuo, S. et al. Revised equations for estimated GFR from serum creatinine in Japan. Am. J. Kidney Dis. 53, 982-992 (2009).

25. Kaga, H. et al. Comparison of measurements of anti-PLA2R antibodies in Japanese patients with membranous nephropathy using in-house and commercial ELISA. Clin. Exp. Nephrol. 23, 465-473 (2019).

26. Komatsuda, A. et al. Monoclonal immunoglobulin deposition disease associated with membranous features. Nephrol. Dial. Transplant. 23, 3888-3894 (2008).

27. Miyakawa, R. et al. Comparative proteomic analysis of renal proteins from IgA nephropathy model mice and control mice. Clin. Exp. Nephrol. 24, 666-679 (2020).

28. Gastinel, L. N. Principle component analysis in the era of <<omics >> data in Principle component analysis - Multidisciplinary applications (ed. Sanguansat, P.) 21-42 (InTech, 2012).

\section{Tables}

Table 1. Clinical characteristics of patients with membranous nephropathy included in this study and control subjects. $B C L$, bucillamine; $\mathrm{Cr}$, creatinine; eGFR, estimated glomerular filtration rate; MN, membranous nephropathy; PLA2R, phospholipase A2 receptor. *Measured by the Euroimmun enzyme-linked immunosorbent assay system. 


\begin{tabular}{|c|c|c|c|c|}
\hline & $\begin{array}{l}\text { PLA2R (+) MN } \\
\text { patients }\end{array}$ & $\begin{array}{l}\text { PLA2R (-) MN } \\
\text { patients }\end{array}$ & $\begin{array}{l}\text { BCL-induced MN } \\
\text { patients }\end{array}$ & $\begin{array}{l}\text { Transplantation } \\
\text { donors }\end{array}$ \\
\hline Number of patients and controls & 6 & 6 & 6 & 5 \\
\hline Median age (years) (range) & $63(60-67)$ & $78(41-82)$ & $45(33-61)$ & $53(45-77)$ \\
\hline Male:female & $3: 3$ & $3: 3$ & $1: 5$ & $1: 4$ \\
\hline $\begin{array}{l}\text { RLA2R antibody titer (positive: } \geq 14 \\
\mathrm{RU} / \mathrm{mL} \text { )* }\end{array}$ & $36.8(35.3-576.9)$ & $0(0-1.5)$ & & \\
\hline $\begin{array}{l}\text { Median proteinuria ( } \mathrm{g} / \mathrm{gCr} \text { or } \mathrm{g} / \text { day) at } \\
\text { biopsy (range) }\end{array}$ & $10.0(5.3-21.0)$ & $3.7(2.6-23.7)$ & $0.5(0.2-5.5)$ & $0.7(0.1-0.9)$ \\
\hline $\begin{array}{l}\text { Median maximum level during BCL } \\
\text { therapy (range) }\end{array}$ & & & $4.8(1.7-8.8)$ & \\
\hline $\begin{array}{l}\text { Median minimum level after BCL } \\
\text { withdrawal (range) }\end{array}$ & & & $0.2(0.1-0.7)$ & \\
\hline Median serum albumin (g/dL) (range) & $2.2(1.2-2.9)$ & $3.0(1.0-3.2)$ & $3.1(2.8-4.0)$ & $4.3(3.5-4.5)$ \\
\hline Nephrotic syndrome, $n$ & 6 & 4 & 2 & \\
\hline Median serum $\mathrm{Cr}(\mathrm{mg} / \mathrm{dL})$ (range) & $0.64(0.49-0.90)$ & $0.58(0.39-0.90)$ & $0.40(0.40-0.86)$ & $0.67(0.60-0.90)$ \\
\hline Median eGFR $\left(\mathrm{ml} / \mathrm{min} / 1.73 \mathrm{~m}^{2}\right)$ (range) & $72.1(65.7-94.4)$ & $\begin{array}{l}99.7(74.9- \\
124.6)\end{array}$ & $131(66.4-143.2)$ & $72.1(66.9-81.6)$ \\
\hline
\end{tabular}

Table 2. Pathological characteristics of patients with membranous nephropathy included in this study. BCL, bucillamine; IF, immunofluorescence; Ig, immunoglobulin; MN, membranous nephropathy; NA, not available; PLA2R, phospholipase A2 receptor.

\begin{tabular}{llll} 
& PLA2R (+) MN patients & PLA2R (-) MN patients & BCL-induced MN patients \\
\hline Glomerular IgG deposition (IF intensities), $n$ & $4(2+), 2(3+)$ & $2(+), 2(2+), 2(3+)$ & $2(+), 1(2+), 3(3+)$ \\
\hline IgG1 (IF intensities), $n$ & $5(-), 1( \pm)$ & $6(-)$ & $1( \pm), 3(+), 2(2+)$ \\
\hline IgG2 (IF intensities), $n$ & $3(-), 2(+), 1(2+)$ & $1(-), 1( \pm), 3(+), 1(2+)$ & $2(+), 2(2+), 2(3+)$ \\
\hline IgG3 (IF intensities), $n$ & $4(-), 2(+)$ & $5(-), 1(+)$ & $5(-), 1(+)$ \\
\hline IgG4 (IF intensities), $n$ & $2(+), 1(2+), 3(3+)$ & $2(-), 1(+), 3(2+)$ & $3(-), 1( \pm), 2(+)$ \\
\hline Glomerular IgA deposition (IF intensities), $n$ & $3(-), 1( \pm), 1(+), 1(2+)$ & $1(-), 2( \pm), 2(+), 1(2+)$ & $2(-), 2(+), 2(2+)$ \\
\hline Glomerular IgM deposition (IF intensities), $n$ & $5(-), 1(+)$ & $2(-), 3( \pm), 1(+)$ & $1(-), 2( \pm), 2(+), 1(2+)$ \\
\hline Glomerular K deposition (IF intensities), $n$ & $2(+), 2(2+), 2(3+)$ & $1( \pm), 1(+), 3(2+), 1(3+)$ & $1( \pm), 2(+), 1(2+), 2(3+)$ \\
\hline Glomerular $\lambda$ deposition (IF intensities), $n$ & $2(+), 2(2+), 2(3+)$ & $1( \pm), 1(+), 3(2+), 1(3+)$ & $2(+), 2(2+), 2(3+)$ \\
\hline Glomerular C3 deposition (IF intensities), $n$ & $4(+), 2(2+)$ & $1(-), 1( \pm), 4(+)$ & $3( \pm), 2(+), 1(3+)$ \\
\hline Glomerular C1q deposition (IF intensities), $n$ & $6(-)$ & $5(-), 1( \pm)$ & $3(-), 2(+), 1(2+)$
\end{tabular}

Table 3. List of immunoglobulins. BCL, bucillamine; C, constant; DB, database; Ig, immunoglobulin; NCBInr, National Cancer for Biotechnology Information non-redundant; PLA2R, phospholipase A2 receptor, pMN, primary membranous nephropathy; sMN, secondary membranous nephropathy. ${ }^{*} P<0.05, * \star P<0.01$. 


\begin{tabular}{|c|c|c|c|c|c|c|c|}
\hline $\begin{array}{l}\text { Accession } \\
\text { ID }\end{array}$ & $\begin{array}{l}\text { Accession } \\
\text { ID }\end{array}$ & Protein name & Sequence & Peptide & $\begin{array}{l}\text { PLA2R (+) pMN } \\
\text { patients / }\end{array}$ & $\begin{array}{l}\text { PLA2R (-) } \\
\text { pMN patients / }\end{array}$ & $\begin{array}{l}\text { BCL-induced } \\
\text { sMN patients / }\end{array}$ \\
\hline NCBInr DB & $\begin{array}{l}\text { GenBank } \\
\text { DB }\end{array}$ & & $\begin{array}{l}\text { coverage } \\
(\%)\end{array}$ & $\underset{(n)}{\operatorname{match}}$ & $\begin{array}{l}\text { Transplantation } \\
\text { donors (ratio) }\end{array}$ & $\begin{array}{l}\text { Transplantation } \\
\text { donors (ratio) }\end{array}$ & $\begin{array}{l}\text { Transplantation } \\
\text { donors (ratio) }\end{array}$ \\
\hline 34527425 & AK130586.1 & $\begin{array}{l}\lg \text { Y1 heavy } \\
\text { chain } \mathrm{C} \text { region }\end{array}$ & 20 & 7 & 2.21 & 2.08 & 3.25 \\
\hline 34535785 & AK128421.1 & $\begin{array}{l}\lg \text { Y2 heavy } \\
\text { chain C region }\end{array}$ & 12 & 5 & 1.95 & 3.11 & 2.44 \\
\hline 34535866 & AK128477.1 & $\begin{array}{l}\text { Ig } Y 4 \text { heavy } \\
\text { chain } \mathrm{C} \text { region }\end{array}$ & 17 & 6 & $100 * \star$ & $100 * *$ & $100 * *$ \\
\hline 229537 & & $\begin{array}{l}\text { Ig a heavy } \\
\text { chain }\end{array}$ & 12 & 5 & 3.48 & 3.02 & 2.95 \\
\hline 33451 & $\mathrm{X} 17115.1$ & $\begin{array}{l}\lg \mu \text { heavy } \\
\text { chain }\end{array}$ & 9 & 5 & 3.04 & 4.12 & 3.95 \\
\hline 229526 & & Ig $\mathrm{k}$ light chain & 25 & 3 & 21.16 ** & $12.28^{*}$ & 12.33 ** \\
\hline 576865216 & & $\lg \lambda$ light chain & 23 & 3 & 1.84 & 1.84 & 4.43 \\
\hline
\end{tabular}

Table 4. List of complements and complement-regulating proteins. BCL, bucillamine; C4BPA, C4b-binding protein a chain; CFHR, complement factor H-related protein; CR, complement receptor, DB, data base; NCBInr, National Cancer for Biotechnology Information non-redundant; PLA2R, phospholipase A2 receptor, PMN, primary membranous nephropathy; sMN, secondary membranous nephropathy. $\quad * * P<0.01$.

\begin{tabular}{llllllll}
$\begin{array}{l}\text { Accession } \\
\text { ID }\end{array}$ & $\begin{array}{l}\text { Accession } \\
\text { ID }\end{array}$ & $\begin{array}{l}\text { Protein } \\
\text { name }\end{array}$ & Sequence & Peptide & $\begin{array}{l}\text { PLA2R }(+) \text { pMN } \\
\text { patients } /\end{array}$ & $\begin{array}{l}\text { PLA2R (-) pMN } \\
\text { patients } /\end{array}$ & $\begin{array}{l}\text { BCL-induced } \\
\text { sMN patients / }\end{array}$ \\
\hline NCBInr DB & $\begin{array}{l}\text { GenBank } \\
\text { DB }\end{array}$ & & $\begin{array}{l}\text { coverage } \\
(\%)\end{array}$ & $\begin{array}{l}\text { match } \\
(n)\end{array}$ & $\begin{array}{l}\text { Transplantation } \\
\text { donors (ratio) }\end{array}$ & $\begin{array}{l}\text { Transplantation } \\
\text { donors (ratio) }\end{array}$ & $\begin{array}{l}\text { Transplantation } \\
\text { donors (ratio) }\end{array}$ \\
\hline 115298678 & & C3 & 23 & 38 & 7.49 & 4.98 & 3.21 \\
\hline 443671 & & C4A & 12 & 17 & $100 * *$ & $100 * *$ & $100 * *$ \\
\hline 40737478 & & C4A3 & 14 & 5 & $100 * *$ & $100 * *$ & $100 * *$ \\
\hline 119576392 & & C9 & 12 & 7 & 7.13 & 7.51 & 2.69 \\
\hline 118442839 & & CFHR1 & 14 & 4 & & 7.36 & $46.38 * *$ \\
\hline 767910533 & & CFHR5 & 10 & 6 & $100 * *$ & $100 * *$ & 100 \\
\hline 578815184 & & Clusterin & 25 & 13 & 2.15 & 2.14 & 1.49 \\
\hline 809019 & X05309.1 & CR1 & 3 & 3 & 2.05 & 2.24 & 4.28 \\
\hline 194383558 & AK303793.1 & C4BPA & 13 & 7 & 1.79 & 2.37 & 1.22 \\
\hline 13477169 & & Vitronectin & 18 & 7 & 2.72 & 2.87
\end{tabular}

Table 5. List of podocyte-associated proteins. BCL, bucillamine; DB, data base; NCBInr, National Cancer for Biotechnology Information non-redundant; PLA2R, phospholipase A2 receptor, pMN, primary membranous nephropathy; sMN, secondary membranous nephropathy; THSD7A, thrombospondin type-1 domain-containing 7A; Zo-1, zonula occludens-1. ** $P<0.01$. 


\begin{tabular}{|c|c|c|c|c|c|c|c|}
\hline $\begin{array}{l}\text { Accession } \\
\text { ID }\end{array}$ & $\begin{array}{l}\text { Accession } \\
\text { ID }\end{array}$ & Protein name & Sequence & Peptide & $\begin{array}{l}\text { PLA2R (+) pMN } \\
\text { patients / }\end{array}$ & $\begin{array}{l}\text { PLA2R (-) } \\
\text { pMN patients / }\end{array}$ & $\begin{array}{l}\text { BCL-induced } \\
\text { sMN patients / }\end{array}$ \\
\hline NCBInr DB & $\begin{array}{l}\text { GenBank } \\
\text { DB }\end{array}$ & & $\begin{array}{l}\text { coverage } \\
(\%)\end{array}$ & $\begin{array}{l}\text { match } \\
(n)\end{array}$ & $\begin{array}{l}\text { Transplantation } \\
\text { donors (ratio) }\end{array}$ & $\begin{array}{l}\text { Transplantation } \\
\text { donors (ratio) }\end{array}$ & $\begin{array}{l}\text { Transplantation } \\
\text { donors (ratio) }\end{array}$ \\
\hline 150170672 & & THSD7A & 2 & 3 & 0.97 & 1.80 & 2.05 \\
\hline 204306657 & & Nephrin & 3 & 4 & 0.73 & 0.81 & 0.98 \\
\hline 7657615 & & Podocin & 9 & 3 & 1.59 & 1.82 & 2.55 \\
\hline 1034591669 & & Zo-1 & 8 & 12 & 1.51 & 1.81 & 1.20 \\
\hline 5453599 & & $\begin{array}{l}\text { F-actin- } \\
\text { capping } \\
\text { protein a2 }\end{array}$ & 18 & 4 & 4.55 & 4.92 & 1.67 \\
\hline 578810794 & & Synaptopodin & 15 & 11 & 1.36 & 1.30 & 1.54 \\
\hline 12025678 & & a-actinin-4 & 58 & 44 & 1.68 & 1.62 & 1.09 \\
\hline 12667788 & & Myosin-9 & 11 & 19 & 1.87 & 1.87 & 1.15 \\
\hline 219520307 & BC143318.1 & Podocalyxin & 9 & 5 & 2.33 & 3.21 & 1.86 \\
\hline 119615053 & & Integrin a3 & 6 & 6 & 0.85 & 1.01 & 1.35 \\
\hline 76879682 & & Nestin & 30 & 28 & 8.40 & 0.46 & $0.01 * \star$ \\
\hline 62414289 & & Vimentin & 80 & 59 & 3.10 & 2.48 & 1.23 \\
\hline
\end{tabular}

Table 6. List of glomerular basement membrane proteins. BCL, bucillamine, COL, collagen; DB, data base; HSPG, heparan sulfate proteoglycan; NCBInr, National Cancer for Biotechnology Information non-redundant; PLA2R, phospholipase A2 receptor, pMN, primary membranous nephropathy; sMN, secondary membranous nephropathy. ${ }^{*} P<0.05,{ }^{\star} P<0.01$.

\begin{tabular}{|c|c|c|c|c|c|c|c|}
\hline $\begin{array}{l}\text { Accession } \\
\text { ID }\end{array}$ & $\begin{array}{l}\text { Accession } \\
\text { ID }\end{array}$ & $\begin{array}{l}\text { Protein } \\
\text { name }\end{array}$ & Sequence & Peptide & $\begin{array}{l}\text { PLA2R (+) pMN } \\
\text { patients / }\end{array}$ & $\begin{array}{l}\text { PLA2R (-) pMN } \\
\text { patients / }\end{array}$ & $\begin{array}{l}\text { BCL-induced SMN } \\
\text { patients / }\end{array}$ \\
\hline NCBInr DB & $\begin{array}{l}\text { GenBank } \\
\text { DB }\end{array}$ & & $\begin{array}{l}\text { coverage } \\
(\%)\end{array}$ & $\begin{array}{l}\operatorname{match}_{(n)} \\
\end{array}$ & $\begin{array}{l}\text { Transplantation } \\
\text { donors (ratio) }\end{array}$ & $\begin{array}{l}\text { Transplantation } \\
\text { donors (ratio) }\end{array}$ & $\begin{array}{l}\text { Transplantation } \\
\text { donors (ratio) }\end{array}$ \\
\hline 125987809 & & COL4A1 & 6 & 5 & 0.15 * & 0.07 ** & 0.38 \\
\hline 116256354 & & COL4A2 & 5 & 6 & 0.77 & 0.71 & 0.57 \\
\hline 119591260 & & COL4A3 & 7 & 6 & 0.87 & 1.00 & 1.39 \\
\hline 116256356 & & COL4A4 & 4 & 4 & 0.56 & 1.12 & 1.08 \\
\hline 1034673478 & & COL4A5 & 4 & 4 & 1.98 & 1.58 & 1.48 \\
\hline 20147503 & & $\begin{array}{l}\text { Laminin } \\
\text { a5 }\end{array}$ & 19 & 61 & 0.80 & 0.82 & 0.83 \\
\hline 1103585 & & $\begin{array}{l}\text { Laminin } \\
\beta 2\end{array}$ & 30 & 46 & 1.01 & 1.06 & 0.94 \\
\hline 145309326 & & $\begin{array}{l}\text { Laminin } \\
\text { y1 }\end{array}$ & 17 & 25 & 0.73 & 0.92 & 0.81 \\
\hline 119590445 & & $\begin{array}{l}\text { Nidogen- } \\
1\end{array}$ & 21 & 27 & 1.24 & 1.23 & 1.20 \\
\hline 530360311 & & Agrin & 28 & 43 & 0.80 & 1.00 & 0.97 \\
\hline 11602963 & & $\begin{array}{l}\text { HSPG } \\
\text { perlecan }\end{array}$ & 15 & 49 & 1.12 & 1.07 & 1.06 \\
\hline
\end{tabular}


Table 7. List of glomerular proteins other than proteins listed in Tables 3-6. BCL, bucillamine; COL, collagen; DB, data base; FBOX50, F-box only protein $\mathbf{5 0}$ (now known as ubiquitin ligase); NCBInr, National Cancer for Biotechnology Information non-redundant; PLA2R, phospholipase A2 receptor, PMN, primary membranous nephropathy; sMN, secondary membranous nephropathy. ${ }^{*} P<$ 0.01 .

\begin{tabular}{|c|c|c|c|c|c|c|c|}
\hline $\begin{array}{l}\text { Accession } \\
\text { ID }\end{array}$ & $\begin{array}{l}\text { Accession } \\
\text { ID }\end{array}$ & Protein name & Sequence & Peptide & $\begin{array}{l}\text { PLA2R (+) pMN } \\
\text { patients / }\end{array}$ & $\begin{array}{l}\text { PLA2R (-) pMN } \\
\text { patients / }\end{array}$ & $\begin{array}{l}\text { BCL-induced } \\
\text { sMN patients / }\end{array}$ \\
\hline NCBInr DB & $\begin{array}{l}\text { GenBank } \\
\text { DB }\end{array}$ & & $\begin{array}{l}\text { coverage } \\
(\%)\end{array}$ & $\begin{array}{l}\text { match } \\
(n)\end{array}$ & $\begin{array}{l}\text { Transplantation } \\
\text { donors (ratio) }\end{array}$ & $\begin{array}{l}\text { Transplantation } \\
\text { donors (ratio) }\end{array}$ & $\begin{array}{l}\text { Transplantation } \\
\text { donors (ratio) }\end{array}$ \\
\hline 119585300 & & COL7A1 & 1 & 3 & 0.54 & 1.33 & 15.51 ** \\
\hline 215274264 & & COL18A1 & 6 & 9 & 3.27 & 3.15 & 2.74 \\
\hline 61680528 & & Calmodulin & 42 & 6 & $100 * \star$ & $100 * *$ & $100: * \star$ \\
\hline 2627129 & & Polyubiquitin & 32 & 4 & 4.70 & 4.60 & 2.65 \\
\hline 47825361 & & $\begin{array}{l}\text { FBOX50 } \\
\text { (ubiquitin } \\
\text { ligase) }\end{array}$ & 12 & 3 & 3.36 & 3.76 & 3.30 \\
\hline
\end{tabular}

\section{Figures}




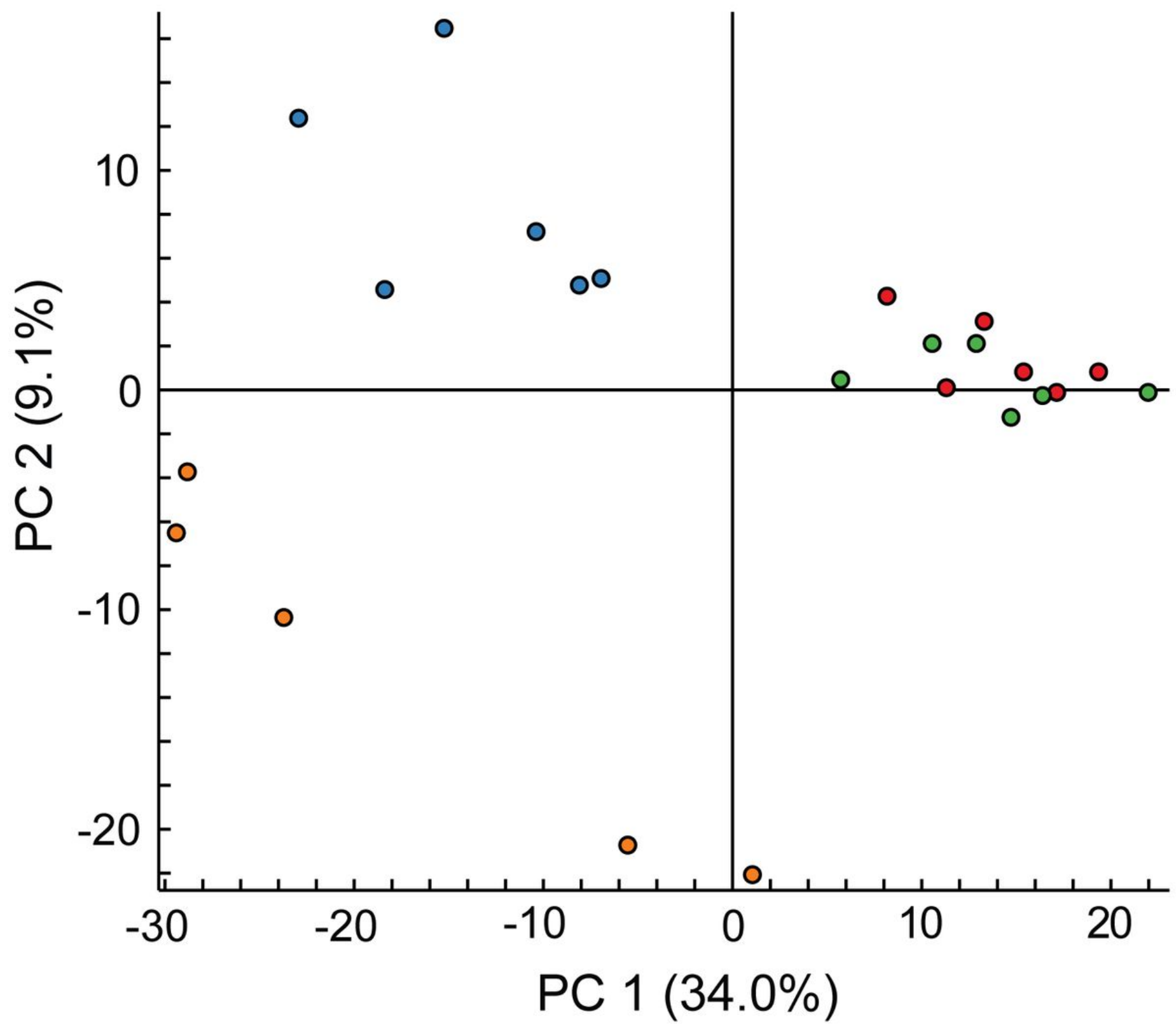

Figure 1

Principle component analysis. The data obtained for 6 patients with PLA2R (+) pMN, 6 patients with PLA2 (-) pMN, 6 patients with BCL-induced sMN, and 5 control patients (time 0 trans plant biopsies) are shown. The data for the PLA2R (+) pMN, PLA2 (-) pMN, BCL-induced SMN, and control groups are represented by red, green, blue, and orange dots, respectively. 